\title{
A Study of Correlation of Serum Chromium Level with Glycosylated Haemoglobin (HbA1c), Total Cholesterol and Triglycerides, among Type 2 Diabetes Patients
}

\author{
Hani M. Mohamed1 ${ }^{*}$, Isam M. Sadik ${ }^{2}$, Abdelgadir Eltom³ ${ }^{3}$ Ahmed L. Osman³, \\ Asaad MA. Babker ${ }^{3}$ \\ ${ }^{1}$ Department of Clinical Chemistry, College of Medical Laboratories Science, University for Sciences and Technology, \\ Omdurman, Sudan \\ ${ }^{2}$ Department of Clinical Chemistry, Faculty of Medical Laboratories Science, Omdurman Islamic University, Khartoum, Sudan \\ ${ }^{3}$ Department of Medical Laboratory Sciences, College of Health Sciences, Gulf Medical University, Ajman, UAE \\ Email: ^hani.kardash@gmail.com
}

How to cite this paper: Mohamed, H.M., Sadik, I.M., Eltom, A., Osman, A.L. and Babker, A.MA. (2019) A Study of Correlation of Serum Chromium Level with Glycosylated Haemoglobin (HbAlc), Total Cholesterol and Triglycerides, among Type 2 Diabetes Patients. Open Journal of Blood Diseases, 9, 1-8.

https://doi.org/10.4236/ojbd.2019.91001

Received: January 2, 2019

Accepted: January 18, 2019

Published: January 21, 2019

Copyright $\odot 2019$ by author(s) and Scientific Research Publishing Inc. This work is licensed under the Creative Commons Attribution International License (CC BY 4.0).

http://creativecommons.org/licenses/by/4.0/

\section{(c) (i) Open Access}

\begin{abstract}
Background: Diabetes mellitus is a common disease and it is a major cause of morbidity; several studies indicate that diabetes is a likely under reported cause of death. Chromium's is important trace element to control diabetes mellitus and metabolism of carbohydrate, lipid and protein. Objective: The purpose of this study was to understand the relationship between serum chromium, with $\mathrm{HbAlc}$, Total cholesterol and Triglycerides among type 2 diabetes patients among diabetic patients. Methodology: This is cross-sectional study done in Jabber Abu Ezz Centre for treatment and care of diabetics in Khartoum-Sudan. Four hundred subjects were enrolled in this study; one hundred subjects were normal healthy as control group, and three hundred subjects diabetic patient type 2 as test group; demographic and biochemical data were collected; serum chromium, Glycosylated Haemoglobin (HbAlc), Total cholesterol Triglycerides, were determined by using NYCOCARD READER II, spectrophotometer (Biosystem 310) and spectrophotometer 210-VGP. Result: In this study there is significant parameters level means of FBS HbA1c, Total Cholesterol, Triglycerides and Chromium of the test groups when compared with healthy control groups subjects $(P=0.001$, $0.018,0.01,0.011,0.004)$, respectively. Significant negative correlation is between FBS, HbA1c, Total Cholesterol, Triglycerides and Chromium $(\mathrm{r}=$ $-0.555, \mathrm{P}$ value $=0.003),(\mathrm{r}=-0.668, \mathrm{P}$ value $=0.002),(\mathrm{r}=-0.335, \mathrm{P}$ value $=$ $0.004)$ and $(r=-0.774, P$ value $=0.002)$ respectively. Conclusion: There was
\end{abstract}


significant correlation between serum Chromium level with fasting blood sugaer, Glycosylated Haemoglobin (HbA1c), Total cholesterol and Triglycerides among type 2 diabetes patients.

\section{Keywords}

Type 2 Diabetes Mellitus, Chromium, Glycosylated Haemoglobin, Total Cholesterol, Triglycerides

\section{Introduction}

Diabetes mellitus (DM) is a group of metabolic diseases characterized by increased blood glucose level resulting from defects in insulin secretion, insulin action, or both [1]. Dyslipidemia is a major risk factor for coronary heart disease. Type 2 diabetes is associated with a cluster of interrelated plasma lipid and lipoprotein abnormalities [2].

The metabolism of several minerals has been reported to alter in diabetes mellitus and these elements might have specific role in the pathogenesis and progress of the disease. Among these the trace elements-chromium is important for the growth and biological functions [3]. Type 2 diabetes is the commonest form of diabetes and associated with multiple metabolic derangements that result in the excessive production of reactive oxygen species (ROS) and oxidative stress [4]. In diabetes, there are more mechanisms that induce oxidative stress than in normal individuals; such as, glucose auto-oxidation, non-enzymatic glycation of protein, and polyol pathway. These pathways enhance generation of reactive oxygen species (ROS) leading to the tissue damage and causing several complex syndromes in diabetic patients such as cataracts, renal dysfunction, nerve damage, and atherosclerosis. Especially, atherosclerosis leading to the coronary heart disease (CHD) is the major cause of death among diabetics [5]. Trace elements participate in production of reactive oxygen species (ROS), which contribute to oxidative stress. Oxidative stress contributes to the pathogenesis of many diseases including DM. Chromium an essential trace element as well as a vital antioxidant, plays an important role in glucose and lipid metabolism by improving glucose intolerance and lowering elevated lipids. Chromium deficiency affects the maintenance of normal glucose tolerance and healthy lipid profiles [6]. Thus, the aim of our study was to find out the association of the chromium with lipid profile and glycemic control in the patients of type 2 diabetes mellitus.

\section{Materials and Methods}

The study was a descriptive, case control hospital based study. 100 healthy subject were control group with mean FBS $5.3 \mathrm{~m} \cdot \mathrm{mol} / \mathrm{L}$, they were 59 males and 41 females. The age ranged from 27 to 66 years old. The mean age average was 46.67 years. Type 2 diabetic patients were 300 collected by simple random method, the ages ranged from 27 to 78 years old. The mean age average was 46.62 
years. Data were collected using questionnaire. All samples were in a state of fasting for 12 hours, blood specimen (7 ML) was collected and we excluding all over fasting patients, samples kept in a test tube at room temperature then clotted blood sample was centrifuged at 4000 r.p.m and separated, then quickly stored at $-20^{\circ} \mathrm{C}$ till used during the period between March 2014 until January 2017. The study has been approved by the local ethics committee of Medical Director of all hospital. All participants in the study were given their written informed consent considering the aims of the study and sample and clinical information's were used anonymously.

HbA1c assay was done by method based on boronate affinity chromatography using NYCOCARD READER II. Fasting Blood Glucose, Total Cholesterol and Triglycerides was measured by enzymatic method by using spectrophotometer (Biosystem 310) Biosystem Kit Company. Chromium serum level was measured using atomic absorption spectrophotometer 210-VGP Electron of the atom promoted to higher orbital's (excited state) for a short period of time by absorbing a defined quantity of energy. The amount of energy was specific to a particular electron transition in a particular element (chromium). The radiation measured by using detector and the absorbance was converted to analytic concentration. Brief according to the manufacture's protocol, serum chromium was diluted 1:9 with deionized, then diluted serum aspirated and absorbance was measured at wave length $213.9 \mathrm{~nm}$.

\section{Results}

Table 1 shows in this study there is significant parameters level means of FBS $\mathrm{HbA1c}$, Total Cholesterol, Triglycerides and Chromium of the test groups when compared with healthy control groups subjects $(\mathrm{P}=0.001,0.018,0.01,0.011$, 0.004), respectively. Significant negative correlation between FBS, HbA1c, Total Cholesterol, Triglycerides and Chromium $(r=-0.555, \mathrm{P}$ value $=0.003),(\mathrm{r}=$

Table 1. Comparison of the means of Blood Parameters between diabetics and none diabetics.

\begin{tabular}{|c|c|c|c|}
\hline Variables & $\begin{array}{l}\text { None-diabetics } \\
\quad(\mathrm{n}=100)\end{array}$ & $\begin{array}{l}\text { Diabetics } \\
(\mathrm{n}=300)\end{array}$ & $\mathrm{P}$ value \\
\hline $\begin{array}{c}\text { FBS } \\
(\text { Max - Min) }\end{array}$ & $\begin{array}{c}95.5 \pm 8.5 \\
(79.0-110.0) \mathrm{mg} / \mathrm{dL}\end{array}$ & $\begin{array}{c}195.4 \pm 36.0 \\
(127.0-299.0) \mathrm{mg} / \mathrm{dL}\end{array}$ & $0.001^{*}$ \\
\hline $\begin{array}{c}\mathrm{HbA}_{1} \mathrm{c} \% \\
(\mathrm{Max}-\mathrm{Min})\end{array}$ & $\begin{array}{c}4.9 \pm 0.3 \\
(4.4-5.4) \mathrm{mg} / \mathrm{dL}\end{array}$ & $\begin{array}{c}8.4 \pm 1.3 \\
(6.1-12.1) \mathrm{mg} / \mathrm{dL}\end{array}$ & $0.018^{\star}$ \\
\hline $\begin{array}{l}\text { Total Cholesterol } \\
\text { (Max - Min) }\end{array}$ & $\begin{array}{c}144.2 \pm 20.9 \\
(100.0-198.0) \mathrm{mg} / \mathrm{dL}\end{array}$ & $\begin{array}{c}243.1 \pm 21.0 \\
(197.0-280.0) \mathrm{mg} / \mathrm{dL}\end{array}$ & $0.01^{*}$ \\
\hline $\begin{array}{l}\text { Triglycerides } \\
\text { (Max - Min) }\end{array}$ & $\begin{array}{c}113.5 \pm 20.0 \\
(149.0-81.0) \mathrm{mg} / \mathrm{dL}\end{array}$ & $\begin{array}{c}233.3 \pm 55.7 \\
(349.0-145.0) \mathrm{mg} / \mathrm{dL}\end{array}$ & $0.011^{\star}$ \\
\hline $\begin{array}{l}\text { Chromium } \\
\text { (Max - Min) }\end{array}$ & $\begin{array}{c}0.229 \pm 0.112 \\
(0.440-0.050) \mathrm{mcg} / \mathrm{mL}\end{array}$ & $\begin{array}{c}0.033 \pm 0.004 \\
(0.039-0.012) \mathrm{mcg} / \mathrm{mL}\end{array}$ & $0.004^{\star}$ \\
\hline
\end{tabular}

${ }^{\star}$ Significant differences in all blood parameters between control and test group (P value $\left.<0.05\right)$. 
$-0.668, \mathrm{P}$ value $=0.002),(\mathrm{r}=-0.335, \mathrm{P}$ value $=0.004)$ and $(\mathrm{r}=-0.774, \mathrm{P}$ value $=$ 0.002 ) $0.001, \mathrm{P}=0.012$ ) (Figures $1-4$ ) respectively.

\section{Discussion}

The present study showed that a significant elevation of the means of the serum levels of total cholesterol of the test group when compared with the control group, these findings agree with the result of $\mathrm{P}$, Annapurna et al. [7], who found significant raised in the means of the plasma levels of total. In our study the diabetic patients have a significant reduction in the means of their serum levels of

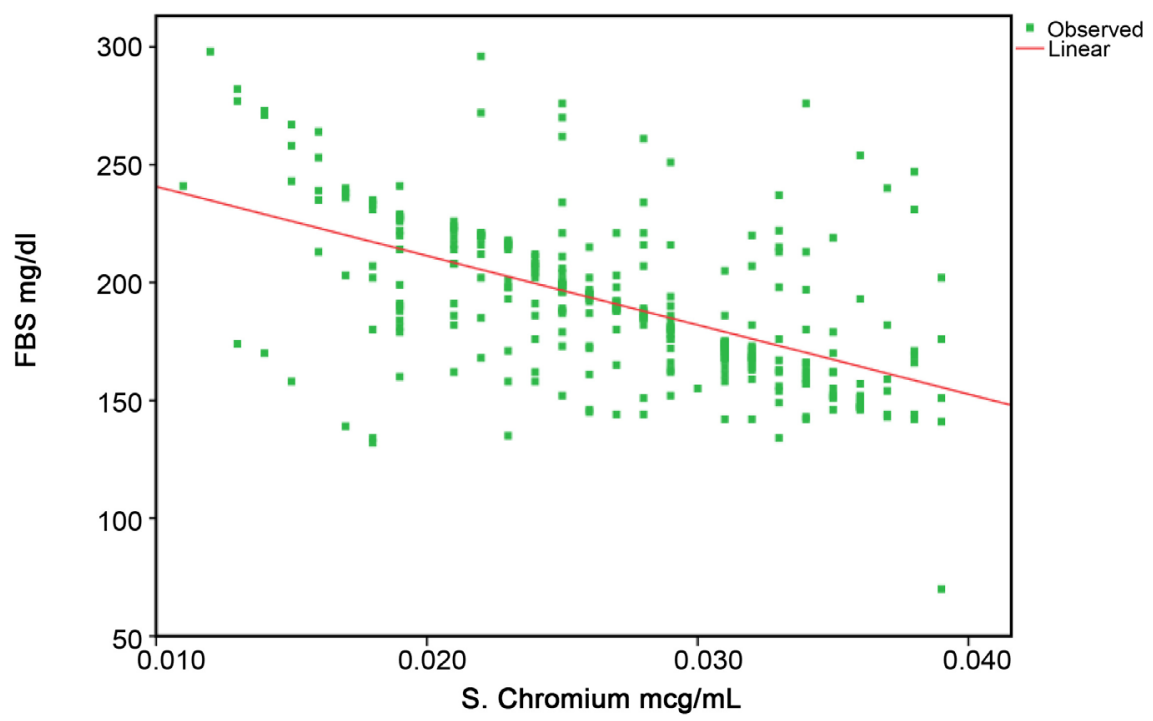

Figure 1. Scatter plot shows the relationship between serum chromium and serum FBS of the test group $(\mathrm{N}=300)(\mathrm{r}=-0.555, \mathrm{P}$ value $=0.003)$.

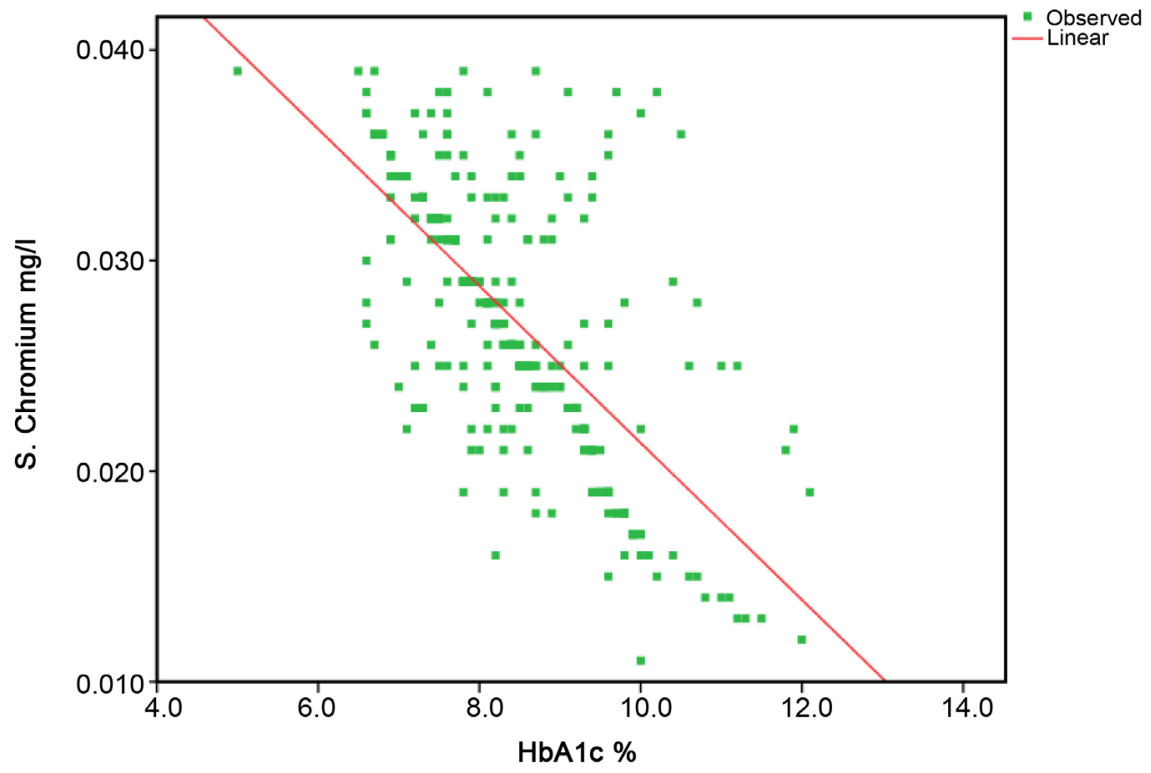

Figure 2. Scatter plot shows the relationship between $\mathrm{HbA} 1 \mathrm{c} \%$ and serum chromium of the test group $(\mathrm{N}=300)(\mathrm{r}=-0.668, \mathrm{P}$ value $=0.002)$. 


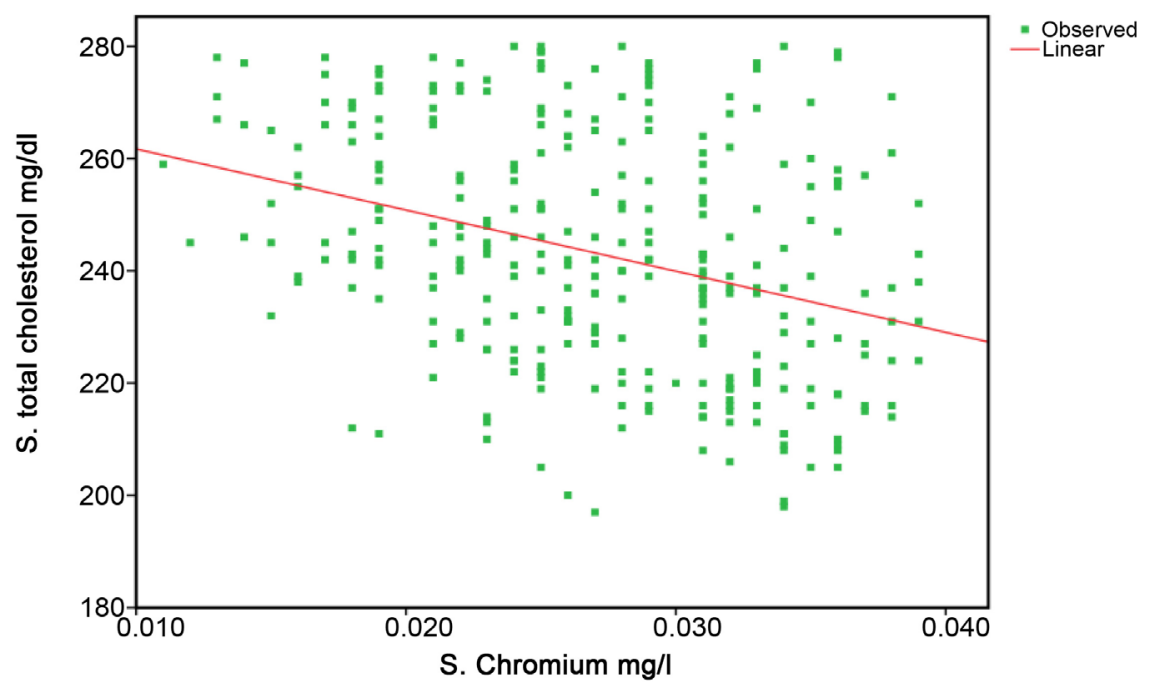

Figure 3. Scatter plot shows the relationship between serum chromium and serum total cholesterol of the test group $(\mathrm{N}=300)(\mathrm{r}=-0.335$, $\mathrm{P}$ value $=0.004)$.

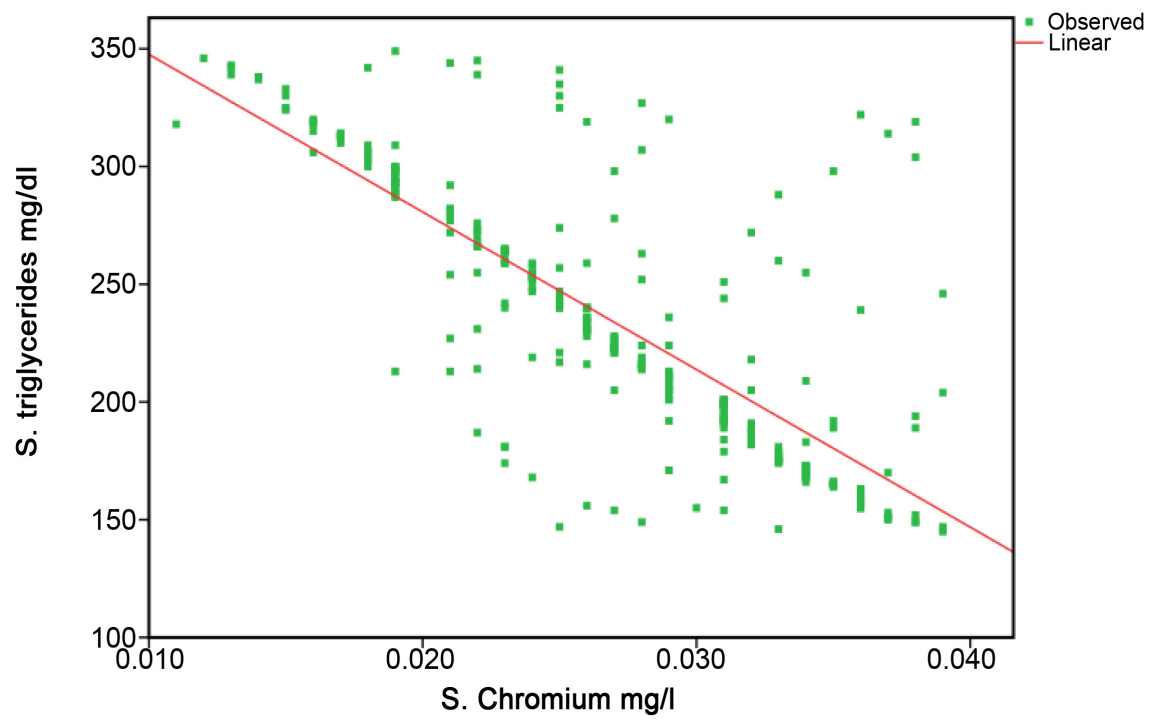

Figure 4. Scatter plot shows the relationship between serum chromium and serum triglycerides cholesterol of the test group $(\mathrm{N}=300)(\mathrm{r}=-0.774$, $\mathrm{P}$ value $=0.002)$.

cholesterol when compared to the control group, this result agrees with that reported by Rosmee and K. Shyamal [8], who found the mean of the serum levels of HDLc was significantly lower in diabetic obese patients than in the control subjects. A study done by Wexler et al. [9] obtained a result that was not in concordance with our result in which the lipid profile were higher in diabetic patients. In our study we found the diabetic patients have a significant elevation in the means of the serum levels of LDL cholesterol when compared to the control group, this result agrees with that reported by M, G Bhutto [10] in a study done in India, who found the mean of the serum levels of LDLc was significantly elevation in diabetic patients than in the control subjects. The current study shows a significant elevation of the mean of the serum levels of triglycerides among the 
diabetic patients when compared to the control group, this agrees with a study done by Sarkar Chandra Bidan [11], who found the mean of the serum levels of triglycerides of the test group was significantly raised when compared with the control group. In our study the diabetic patients have a significant reduction in the means of the serum levels of chromium when compared to the control group, this result agrees with that reported by Rajendran Kannan et al. [12], who found the mean of the serum levels of chromium was significantly lower in diabetic patients than in the control subjects, this is in coordination with the findings of Morris et al. [13], Ekmekcioglu et al. [14], and Kazi et al. [15] that indicated lower blood levels of chromium in diabetics than in nondiabetics. The explanation of this result can be obtained from other studies which showed that the rates of absorption and excretion of chromium in diabetics are more than in nondiabetics (Anderson et al. also SHRABANI M et al. [16] [17]; Hamad et al. [18]). As a result of this, supplemental $\mathrm{Cr}$ was tried and found to have beneficial effects on people with glucose intolerance, diabetes, obesity, and neuropathy had experiments that showed reduction in blood glucose levels as a response to chromium supplementation [16] [18]. In our study we observed a significant Negative correlation between the serum levels of total cholesterol and the serum chromium, this result agrees with that reported by A, I. Ahmed, \& M, M. Helal et al. [19], in a study done in Egypt, who found a significant Negative correlation between the serum chromium and the serum levels of the total cholesterol. In our study shows negative correlation between the serum levels of triglycerides cholesterol and the serum chromium, this agrees with that reported by Ahmed, \& M, M. Helal et al. [19], in a study done in Egypt, who found negative correlation between the serum triglycerides cholesterol and the serum chromium.

\section{Conclusion}

There was significant correlation between serum Chromium level with fasting blood sugaer, Glycosylated Haemoglobin (HbAlc), Total Cholesterol and Triglycerides among type 2 diabetes patients. Deficient chromium level, as their vital role in lipids metabolism and insulin function chromium supplementation are essential in the control of glycemic metabolism and lipid profile in DM2.

\section{Acknowledgements}

We are grateful to them all for participating in our study and special thanks to the staff of Jabber Abu Ezz Centre for treatment and care of diabetics in Khartoum Sudan.

\section{Conflicts of Interest}

There are no conflicts of interests between authors.

\section{References}

[1] American Diabetes Association (2010) Standards of Medical Care in Diabetes- 
2010. Vol. 33, S11-S61.

[2] Krauss, R.M. (2004) Lipids and Lipoproteins in Patients with Type 2 Diabetes. Diabetes Care, 27, 1496-1504. https://doi.org/10.2337/diacare.27.6.1496

[3] Praveeena, S., PaSula, S. and Sameera, K. (2013) Trace Elements in Diabetes Mellitus. Journal of Clinical and Diagnostic Research, 7, 1863-1865.

[4] Matough, F.A., Budin, S.B., Hamid, Z.A., Louis, S.R., Alwahaibi, N. and Mohamed, J. (2012) Palm Vitamin E Reduces Oxidative Stress, and Physical and Morphological Alterations of Erythrocyte Membranes in Streptozotocin-Induced Diabetic Rats. Oxidants and Antioxidants in Medical Science, 1, 59-68.

https://doi.org/10.5455/oams.300412.or.006

[5] Soumy, A.A., Vidya, P., Sabarish, B., Umadevi, P. and Dipu, T.S. (2018) Clozapine-Induced Diabetic Ketoacidosis: A Case Report. Asian Journal of Pharmaceutical and Clinical Research, 11, 1-2.

[6] Lewicki, S., Zdanowski, R., Krzyzowska, M., Lewicka, A., Debski, B., Niemcewicz, M. and Goniewicz, M. (2014) The Role of Chromium III in the Organism and Its Possible Use in Diabetes and Obesity Treatment. Annals of Agricultural and Environmental Medicine, 21, 331-335. https://doi.org/10.5604/1232-1966.1108599

[7] Annapurna, P., Manjunatha, S. and Taklikar, R.H. (2015) Assessment of Serum Lipids in Type II Diabetes Male and Female Patients. Journal of Evidence based Medicine and Healthcare, 2, 7003-7007.

[8] Sharma, R., Sharma, P., Kumar, P. and Tripathi, G.K. (2015) A Correlation between Glycosylated Haemoglobin \& Lipid Profile in Type-2 Diabetes Mellitus with \& without Complications. International Journal of Contemporary Medicine, 3, 115-120. https://doi.org/10.5958/2321-1032.2015.00056.X

[9] Wexler, D.J., Grant, R.W., Meigs, J.B., Nathan, D.M. and Cagliero, E. (2005) Sex Disparities in Treatment of Cardiac Risk Factors in Patients with Type 2 Diabetes. Diabetes Care, 28, 514-520. https://doi.org/10.2337/diacare.28.3.514

[10] Bhutto, M.G., Lokesh, M.R., Shah, S.K.D., Afroze, M.K.H., Ghouse, P. and Abhilash, D. (2017) Association between Lipid Profile and Silent Coronary Artery Disease in South Indian Patients with Type 2 Diabetes Mellitus. International Journal of Advances in Medicine, 4, 6-9.

[11] Sarkar, B.C., Saha, H.R., Azad, A.K., Sana, N.K. and Choudhury, S. (2012) Serum Lipid Profile Status of Type 2 Diabetic Patients in the Cross Section Population in Dhaka City of Bangladesh. Bangladesh Journal of Medical Science, 11, 121-125. https://doi.org/10.3329/bjms.v11i2.11479

[12] Rajendran, K., Manikandan, S., Nair, L.D., Karuthodiyil, R., Vijayarajan, N., Gnanasekar, R., Mohamed, A.S., et al. (2015) Serum Chromium Levels in Type 2 Diabetic Patients and Its Association with Glycaemic Control. Journal of Clinical and Diagnostic Research: JCDR, 9, OC05-8.

[13] Morris, B.W., MacNeil, S., Hardisty, C.A., Heller, S., Burgin, C. and Gray, T.A. (1999) Chromium Homeostasis in Patients with Type II (NIDDM) Diabetes. Journal of Trace Elements in Medicine and Biology, 13, 57-61. https://doi.org/10.1016/S0946-672X(99)80024-8

[14] Ekmekcioglu, C., Prohaska, C., Pomazal, K., Steffan, I., Schernthaner, G. and Marktl, W. (2001) Concentrations of Seven Trace Elements in Different Hematological Matrices in Patients with Type 2 Diabetes as Compared to Healthy Controls. Biological Trace Element Research, 79, 205-219. https://doi.org/10.1385/BTER:79:3:205

[15] Kazi, T.G., Afridi, H.I., Kazi, N., Jamali, M.K., Arain, M.B., Jalbani, N. and 
Kandhro, G.A. (2008) Copper, Chromium, Manganese, Iron, Nickel, and Zinc Levels in Biological Samples of Diabetes Mellitus Patients. Biological Trace Element Research, 122, 1-18. https://doi.org/10.1007/s12011-007-8062-y

[16] Anderson, R.A., Cheng, N., Bryden, N.A., Polansky, M.M., Cheng, N., Chi, J. and Feng, J. (1997) Elevated Intakes of Supplemental Chromium Improve Glucose and Insulin Variables in Individuals with Type 2 Diabetes. Diabetes, 46, 1786-1791.

https://doi.org/10.2337/diab.46.11.1786

[17] Hamad, R.A.W., Krishan, M.M., Quasem, M.J. and Mazahreh, A.S. (2009) The Effect of Chromium Glycinate on the Blood Glucose Control and Blood Lipids of Normal and Diabetic Patients. Pakistan Journal of Nutrition, 8, 900-904.

https://doi.org/10.3923/pin.2009.900.904

[18] Ahmed, A.I. and Helal, M.M. (2012) Serum Chromium Levels in Egyptian Diabetic patients. Comparative Clinical Pathology, 21, 1373-1377.

https://doi.org/10.1007/s00580-011-1299-Z

[19] Shrabani, M., Venkata, B.P. and Roop, A. (2013) Evaluation of Serum Copper, Magnesium and Glycated Haemoglobin in Diabetes Mellitu. Asian Journal of Pharmaceutical and Clinical Research, 6, 188-190. 